\title{
Asian and Latino American Political Conceptualization: A Dual-Concept Model
}

\author{
Bang Quan Zheng
}

bangquan@ucla.edu

August 2021

\begin{abstract}
A central problem for citizens is to understand how their political system works. The classic "Levels of Conceptualization" measure proposed in The American Voter provided an answer for White Americans in the 1950s, but has limited relevance today for citizens of non-European ancestry. Expanding on the work of Campbell et al, this paper develops a measure of Political Conceptualization that combines views about parties and candidates with views on personal identity and ethnic fairness. The measure is based on open-ended responses in a survey of Asian Americans and Latinos. Results show how, across these quite different domains of politics, citizens vary in their Political Conceptualizations from narrow and concrete to broad and abstract. Results highlight the challenge for political organizers in building coalitions among citizens who vary in their understanding of how politics works.
\end{abstract}

Keywords: Partisanship, political conceptualization, politicization, identity, SEM 


\section{Introduction}

Tens of millions of recent Asian American and Latino immigrants to the United States and their children have become strong partisans and regular participants in the political process. Their turnout rates in presidential elections now approach those of native-born Americans and, in contrast to most White Americans, they lean toward the Democratic Party (Hajnal \& Lee, 2011; Huddy, Mason, \& Horwitz, 2016; Sears, Danbold, \& Zavala, 2016; Wong, Ramakrishnan, Lee, \& Junn, 2011). The question addressed in this paper is how these new citizens - in particular, Asian Americans and Latinos - understand the political system and their place in it.

The leading answer to this question for White citizens was proposed by Campbell, Converse, Miller and Stokes in their classic work, The American Voter (1960). In their "Levels of Conceptualization" typology, these scholars argued that only a small fraction of Americans understood politics as most elites did, as a battle of opposing ideologies, liberal and conservative. Most Americans, rather, thought about politics in less abstract and more concrete terms. The modal voter viewed parties in terms of the benefits they confer on groups such as business, working people, and farmers. The next biggest cluster of citizens viewed politics in even more concrete terms, perceiving the parties simply as purveyors of good or bad times. At what the University of Michigan scholars took to be the lowest level of conceptualization, a still substantial fraction of Americans offered no political content when asked about the two parties and their candidates, commenting instead on such matters as mudslinging, campaign lies, and a candidate's divorce. Subsequent research has pointed out certain deficiencies in the approach taken by Campbell et al, but a replication of their study in the 2000 election turned up similar findings (Lewis-Beck, Jacoby, Norpoth, \& Weisberg, 2008)

The American Voter's four-level scheme makes a useful starting point for analysis of how Asian Americans and Latinos understand the American political system. Like other Americans, members of these groups care what values the parties stand for, how the parties are organized, and which party is more likely to deliver valued group benefits and good times (Alvarez \& Garcia Bedolla, 2003; Huddy, Mason, \& Aaroe, 2015b; Uhlaner \& Garcia, 2005). But as a tool for

characterizing how these groups think about politics, the typology has a glaring deficiency: It takes no account of ethnicity. This shortcoming reflects the typology's creation in the 1950s when the vast majority of voters were White and largely unconscious of ethnicity. Conditions are obviously very different today for Asian Americans and Latinos. Most of these new citizens are 
conscious of their ancestry, feel that they have suffered discrimination because of it, and view the U.S. as run mainly by people of European ancestry (Huddy et al., 2016; Junn, 2006a; Junn \& Masuoka, 2008; Uhlaner \& Garcia, 2005). Any effort to characterize how Asian Americans and Latinos conceptualize politics must accommodate these views.

This paper takes up that task. Political conceptualization in my account consists of two dimensions: conceptualization of politics and politicization of identity. I will measure citizen understanding of politics with a new measure which I will call Political Conceptualization, which includes views about parties and candidates as well as views about citizens' own ethnicity in relation to politics. Like the levels measure in The American Voter, my Political Conceptualization measure aims to capture a set of ordered differences in how individuals conceptualize politics, ranging from narrow and concrete at one extreme to broad and abstract at the other.

To build the measure, I conducted a survey of a sample of Asian Americans and Latinos that asked what they like and dislike about the two parties and their candidates, and also what they think about equal opportunity for themselves as members of an ethnic minority, shared interests with other ethnic groups, and personal reactions to major events in ethnic politics, among other matters. All questions were open-ended. The answers were coded by three research assistants into two categorical variables. Answers to questions about parties and candidates were coded into a four-category variable that is essentially a replication of the levels measure in The American Voter, which I call Party Conceptualization. Answers to the questions about the citizens' ethnicity and politics were likewise coded into four categorical levels of conceptualization, which I call Politicized Identity. Citizens who score low on Politicized Identity, who are mostly new arrivals to America, have no clear idea of ethnicity in the United States or how they fit into the political system. Citizens who score high view themselves, their ethnicities, and the political system within a unified intellectual framework.

I hypothesized that Party Conceptualization and Politicized Identity would have similar determinants and distributions, behaving as if they were sub-measures of a larger and more general concept, Political Conceptualization. I call Political Conceptualization a "dual-concept measure" to convey the idea that it encompasses two separate variables but nonetheless functions as one coherent variable.

Statistical analysis of these data yielded several important results. Most important was the finding of wide variation in how Asian Americans and Latinos conceptualized politics and 
ethnicity in multi-ethnic America. This variation is important because it shows how immigrants understand their politicized identities - that is, how they think that they fit into the political system. Their understanding varies from narrow and concrete to broad and abstract in the same way that Party Conceptualization does. Second, I show that, while Party Conceptualization and Politicized Identity can be measured separately, they are in practice closely related. People who have a concrete and narrow understanding of the party system tend to have a similarly narrow and concrete understanding of how they, as immigrants or descendants of immigrants, relate to that system. This pattern is consistent with my dual concept hypothesis.

\section{Why Party Conceptualization and Politicized Identity?}

The measure of Party Conceptualization used in this study is an adaptation of the one put forth by The American Voter to measure ideological awareness and sophistication among the electorate (Campbell et al., 1960). In this paper, I first use this measure to differentiate immigrants' political conception based on the ascending ideological awareness of the parties, candidates and policies from absence of issue attitudes to ideological evaluation. That is, the lowest level of Party Conceptualization has little issue content, while the highest level is ideology.

The second concept is politicized identity, which refers to the dimensions of people's selfconcept as defined by perceptions of similarity with some people and difference from others in the context of party competition (Citrin \& Sears, 2014; Junn \& Masuoka, 2008). Junn and Masuoka (2008) use the term politicized racial group consciousness, in which they define racial group consciousness as "to understand more generally collective racial group attachment - that is, the willingness of an individual not only to identify with her racial group but also to work with the collective group." The fundamental idea is similar to the politicized group consciousness paradigm elaborated in Citrin and Sears's (2014) research. Within this paradigm, individuals perceive racial and ethnic minority groups as relegated to subordinate positions in American ethnoracial categories, which leads them to identify with the party they view as better at dealing with this problem (Citrin \& Sears, 2014; Sanchez, 2006; Sidanius \& Pratto, 1999; Simon \& Klandermans, 2001; Tajfel \& Turner, 1986). Politicized identity thus structures the patterns and modes of their political motivations. It also encompasses feelings of political commonality and racial consciousness and a willingness to adhere to partisanship. 
In my theoretical view, individuals' levels of Politicized Identity are the outcome of a learning process. With more time observing and experiencing American politics, Asian Americans and Latinos gradually change from thinking of themselves in narrow, concrete and apolitical terms to broad, abstract and partisan ones. Individuals who are in the lowest level of Politicized Identity are typically recent arrivals to America who see little political relevance in their self-perceived social identities, while those in the highest level view the personal as political (Junn \& Masuoka, 2008; Zheng, 2019).

\section{Cognition and affect}

Very little research has examined how immigrant populations understand political system and form politicized identities, and the factors that influence immigrants' attitudes toward the parties. Campbell et al. (1960) was the earliest systematic work regarding American Party Conceptualization. "Levels of Party Conceptualization" in their work show that for White Americans there is sharp variation in the sophistication of their understanding of politics, from no issue content (narrow and concrete) to ideological (broad and abstract). Whereas the Campbell et al. (1960) scheme paid no attention to ethnicity; most of their subjects had been born in the United States and could therefore be assumed to automatically think of themselves as "just Americans." Following the original Campbell et al.'s (1960) framing, most researchers have stressed that voters' level of conceptualization of parties is a cognitive phenomenon and have not investigated possible affective determinants (Lau, 1986; Miller \& Peterson, 2004; Smith, 1980). Yet, it is wellestablished that voters who score high on Levels of Conceptualization are more strongly attached to parties than those who score low. This suggests that levels of conceptualization may have affective as well as cognitive determinants.

From a different perspective, scholars have shown that racial identity can be a key determinant for political behavior among immigrant and minority groups (Alvarez \& Garcia Bedolla, 2003; Barreto \& Segura, 2014; Dawson, 2001; Garcia Bedolla, 2005; Junn \& Masuoka, 2008; Lien, 1994; Lien, Conway, \& Wong, 2003; Parker \& Barreto, 2013; Wong et al., 2011; Zheng, 2019). Yet, existing studies have not studied the politicization of identity in relation to the party system. Politics in the U.S. happens through the mediation of parties (Downs, 1957; Zaller, 1992), which suggests that party and identity conceptualization should be closely related (Green, Palmquis, \& Schickler, 2002; West \& Iyengar, 2020). Social psychologists point out that 
individuals are naturally predisposed to define themselves in terms of group identity, and group members should consciously engage in a political struggle for a more inclusive political representation (Crocker \& Luhtanen, 1990; Simon \& Klandermans, 2001; Tajfel \& Turner, 1986). Party conceptualization and politicized identity are two distinct concepts, and the processes of conceptualizing them are also based on discrete socializations. For non-white immigrants, racial identity is an unescapable component of their social identity (Bobo \& Gilliam, 1990; Huddy, 2001; Sidanius \& Pratto, 1999; Tajfel \& Turner, 1986; Tate, 1994; Turner \& Reynolds, 2003). The sense of racialized group paradigm as argued by Citrin and Sears (2014) can be deeply instilled in intergroup relations, and become part of the political consciousness that is embedded into the development of political conceptualization. Hence, politicization of identity evolves as a series of politicizing stimuli that gradually transform the relationship of individuals to their social environment (Simon \& Klandermans, 2001).

Developing a sophisticated understanding of politics is more challenging for immigrants and their children than for Whites, because they must both figure out how the political system works and also how they fit into that system. The change of social environment and/or individual social status generates new stimuli for attitudinal change. For minority immigrants, the multi-racial social environment and racial hierarchy of American society tend to generate different perceptions of the parties and politics, and different incentives to engage them (Segura, 2013). Hence, there is substantial variation in conceptualization of politics and identity among the immigrant populations (Junn, 2006b; Segura, 2013). Affect is an element of emotion, which is biologically based patterns of perception, experience, communication, etc. that occurs regarding particular political environment or stimuli (Bakker, Schumacher, \& Rooduijn, 2021; Dacher \& Gross, 1999). Racial identities have political relevance that are driven by context and implicit emotional factors (Huddy et al., 2015b; Junn \& Masuoka, 2008). The disparities in political understanding and identity formation are palpable among new and older immigrants, which account for Asian and Latino immigrants' high proportions of nonpartisanship (Hajnal \& Lee, 2006, 2011; Zheng, 2019). Nonetheless, the longer immigrants live in the U.S. the more likely they are to be deeply assimilated into the racial categories, to adopt stronger racial identity, and to nurture stronger attachment to the party system. That is, length of residence can cause increases in both cognitive understanding and emotional attachment. Therefore, immigrants' political conceptualization 
integrates party conceptualization and politicized identity over time - they are both predicted by cognitive and emotional factors.

\section{A dual-concept measure \& typology}

Political Conceptualization aims to capture differences in how citizens understand life experiences. The scheme corresponds to distinct successive stages which are characterized by qualitative differences in both Party Conceptualization and Politicized Identity. The measure of the Party Conceptualization captures the overall breadth of understanding of American parties and electoral politics. In contrast, the measure of Politicized Identity is to evaluate the degree to which Asian American and Latino immigrants develop the self-perceived social identity that is relevant to the party system. For both of these measures, I distinguish and elaborate on four levels of the Party Conceptualization and politicization process from the lowest to highest. My names for the four levels of each measure are:

\begin{tabular}{|c|c|c|}
\hline & Party Conceptualization & Politicized Identity \\
\hline Level 1 & No issue content & Foreigner in America \\
\hline Level 2 & Nature of times & Recognition of Multiethnic America \\
\hline Level 3 & Group benefits & Group-based party politics \\
\hline Level 4 & Ideology & Politicized identity \\
\hline
\end{tabular}

Table 1: Levels of Party Conceptualization and Politicized Identity

\subsection{Levels of Party Conceptualization}

The first level is no issue content, which refers to the stage in which individuals lack cognitive understanding of American politics and society and may feel overwhelmed by the massive flow of information to which they are exposed. The lack of consistent rationale in their attitudes toward American politics and society, their preferences on many issues are contingent upon many random factors, which signifies that there are no issue implications or concerns in the perceptions of the parties. For example, a male respondent in his 40s, who lives in Santa Monica, CA says:

MODERATOR: Do you know the major differences between the Democratic and Republican Party?

MALE: I have lived in California for 7 years, I don't know the differences between Democratic and Republican Party at all, not a bit. I don't have interest in politics, particularly American politics because I don't know English; when I turned on the television, I have no idea what they are talking about. 
MODERATOR: Did you watch ethnic news channel to learn about American politics?

MALE: Occasionally, but rarely pay attention to it.

Another female discussant in her 30s, who has been in the United States for 8 years. In the past 8 years, her cognitive understanding of politics has changed little, simply because there has been an absent of motivations for her to learn the parties.

MODERATOR: Do you know the major differences between the Democratic and Republican Party?

FEMALE: I don't know any of them to be honest. I don't know what is this and what is that. I've been here for 8 years, and 6 years I was a student. I did not even have a TV or looked at the news or anything. So I'm far away from all that to be honest.

Individuals in the second level of Party Conceptualization do not have solid perceptions of group interest, and do not have any sense of a structure of ideological concepts. However, what distinguishes the individuals in this category from those of no issue content is the sense of vague reference to the parties in their responses. However, different from people in the category of no issue content, immigrants in this category have been in the United States for some years and have accumulated some lived experiences; they exhibit the inception of the cognitive understanding of the parties. Yet, the prevalent type of respondents in this category demonstrate that their political reasoning varies more or less between absence of issue content and group interest but they are still quite remote from the concept of ideology. The typical sample of response in this category is a man who is in his 30s and lives in Los Angeles, and he expresses his views on the parties.

MODERATOR: Do you know the major differences between the Democratic Party and Republican Party?

MALE: I rarely pay attention to politics, but from time to time, I heard my colleagues talked about that Hilary Clinton in the last election. They told me if Trump won, he would try to remove the Obamacare. Therefore, I learned that not only Hilary Clinton but also Obama try to help many uninsured people. I believe that is a good thing. Since then, I started to pay attention to politics. But since I don't know much English, my knowledge about the parties is very limited.

Level 3 is group benefits, which refers to a cognitive state in which individuals are aware of the major differences between the parties, their political interests and their association with the 
parties. Hence, respondents in this category evaluate the parties or candidates with references to both group benefits and issues. One of characteristics of responses in this stage is that group interest is increasingly integrated into the evaluation of the parties and the candidates. Despite the fact that respondents operate with a fairly clear sense of the group interest, the liberal-conservative continuum is still on the fringe. A prominent type of response in this category involves racial consciousness in the cognitive understanding of the parties. A female discussant in her 50s from west Los Angeles conveyed that she sometimes disagrees with the Democratic Party on social issues, but racial consciousness is particularly strong and ambiguous.

MODERATOR: Is there anything you like about the Democratic Party?

FEMALE: Yes, I do like how accepting it is of so many different races and it really represents the minorities throughout America giving us a platform to be able to speak and not be shunned to the side. Also, just policy wise I feel like it is just a lot more accepting and forgiving versus the Republican Party is very strict in punishment like the death penalty. I don't support anything like that.

MODERATOR: Is there anything you dislike about the Democratic Party?

FEMALE: I'd say that there are a few things I believe religiously that don't necessarily align with the Democrats. For example, like with abortion I know there are Democrats who believe it should be acceptable under any situation and I don't necessarily agree with that. Like, I think there should be limitations with it not just because an accident happened and then I'm trying to think of what else. I think that in a way it is beneficial to help people who are in need but I think there has to be good restrictions to it because people can take advantage of like the aid that their getting from the government and manipulate it too much and not work. So I think there has to be a balance between the Democratic and Republican ideals when it comes to the economy.

Moreover, people in this level tend to use group benefits to differentiate the impression of the parties or candidates. A female immigrant respondent from El Salvador talked about her impressions of Donald Trump and Barack Obama.

MODERATOR: Is there anything you like about Donald Trump?

FEMALE: Yes I like how he speaks his mind. He's not afraid to say what he thinks and that goes along way for a leader because he's not afraid. But I'm not saying he needs to watch out with what he says because it can come back to him. I like that though because not a lot of leaders express themselves because they're afraid of losing votes or the people that voted for them before.

MODERATOR: Is there anything you dislike about Donald Trump? 
FEMALE: I dislike how the terms he uses to describe people where he's calling one community one word and is saying it inclusively with everyone which isn't correct. I believe there are some people but not everyone.

MODERATOR: Is there anything you like about Barack Obama?

FEMALE: Yes, I would say how he made affordable health care now that Donald Trump has taken it out. I like that. He kept education as one of his top priorities as well for DACA recipients.

MODERATOR: Is there anything you dislike about him?

FEMALE: Something I dislike about him [Obama] is there was a lot more incarceration in his term, I think that's the correct term which is people going to prison during his time. People don't know about this and it was hard to read and understand what he was doing. Going back to the Donald Trump question where he says he's gonna do it but doesn't do it. And Barack Obama did it behind the scenes.

People in the highest level of Party Conceptualization tend to understand politics in ideological terms. Individuals' comments of the parties imply the kinds of conception of politics assumed by ideological interpretations of political behavior and political change (Campbell, Converse, Miller, \& Stokes, 1966; Green et al., 2002; Huddy, 2001). Respondents in this category demonstrate one explicit or implicit ideological mention and make some reference to issues and group benefits. Hence, those who have been in the U.S. for a long period of time and the US born are the majority of this group. These people are well aware of general American politics, and policies and tend to have opinions on many issues that are consistent with their party identifications. A male discussant from Los Angeles conveys his high level of party conceptualization.

MODERATOR: Do you know the major differences between the Democratic and Republican Party?

MALE: I would say a lot, because I feel like overall, they're fighting the same issues. But, as it's stated, or at least from the majority who have been ones that have been more vocal about it, Republicans tend to be more conservative, tend to view thing more in a certain light whereas Democrats tend to be much more liberal and much more open to creating this idea of equality to a certain extent.

MODERATOR: Is there anything you like about the Republican Party?

MALE: No

MODERATOR: Is there anything you dislike about the Republican Party? 
MALE: The conservative aspects that they try push towards society and being very conservative about it. Like same sex marriage, abortion and everything, it feels like taking away the autonomy or the free right of someone to have the right to choose what they want to do with their life.

\subsection{Levels of Politicized Identity}

The lowest level conceptualization in the Politicized Identity immigrants who see themselves as foreigners in a mass of undifferentiated Americans. Their only social identity is their country of national origin, which they see as having no relevance to American politics and which makes them indifferent to American politics. For example, a male discussant in his 30 s, who have been in the U.S. for two years says:

MALE: "People in the United States have too many racial backgrounds, and are too complicated. Other than white and black people, I don't know how to tell the differences between Mexican, Middle Eastern people, and others. To me they look basically the same."

Citizens in the second level of Politicized Identity understand that being a member of an ethnic group is normal in the U.S. Some may even begin to recognize pan-ethnic identity. The transition from self-perception as a foreign outsider to identifying as member of one of the country's many ethnic groups spurs a sense of belonging. For example, a Chinese female discussant in Monterey Park, CA expressed that she did not have an interest in politics, but she knew that she supported the Democratic Party.

MODERATOR: Do you know the major differences between these two parties?

FEMALE: I was told that the Democratic Party is the party that represents the interest for the poor. Almost all of my friends and neighbors always vote for Democrat, so do I. We are immigrants we work hard but don't make a lot of money. Democrat is the party that is more friendly to us, for example, the Obamacare really helped me and my friends a lot. This is all I know.

MODERATOR: How do you like the Republican Party and how do you like the Democratic Party?

FEMALE: I don't know much about it. I feel that they are very complicated. I only know Donald Trump belongs to the Republican Party, and Obama belongs to the Democratic Party. My neighbors and colleagues talked about them from time to time. Particularly Obama, because a black guy became the president was a big conversation topic.

Some individuals recognize the existence of racial hierarchy in the U.S. society but don't interpret racial inequality as a major obstacle to their success. Hence for them, the connection 
between the perception of discrimination and racial identity remains weak. A Latino Republican who has lived in the U.S. for about 6 years told us his feeling.

MODERATOR: How much do you feel that you have equal opportunities in this country as a minority?

MALE: People have told me that there's racism at work and that a lot of employers prefer hiring Caucasian people over people of color. As far as I go, I'm not so concerned. I come from a belief factor that if you're really good enough and if you work hard, all of these things are merely secondary, so I don't care really - I just have to do my best and that's all I can always do.

For many interviewees in Level 2 of Politicized Identity, their political knowledge is limited, and oftentimes they are still confused by politics. The way in which they differentiate the parties usually based on their immigrant background. For example, a Mexican immigrant respondent who has been in the United States for 12 years. He does not have good knowledge of the parties, and his perceptions of the parties are based on the simple group recognition.

MALE: Clearly the Obama administration is more friendly to immigrants than the Trump administration. .... Some of Democrat's policies did not get enacted very well but were wellintended. So, I prefer Obama over Donald Trump.

Level 3 is issue-based group politics. Subjects in this category recognize political issues involving different ethnic groups, but only at the level of particular issues. Different from simple group recognition in the previous category, respondents in this category start to demonstrate a sense of group consciousness, which assumes that individuals come to realize that their individual life chances are interrelated with those of their group (Junn \& Masuoka, 2008). One female discussant in the San Francisco Bay area said that she was indifferent to politics because she had no idea what they were about. After she got married, she started to care about policies that directly influenced her family. She complained that she and her husband paid too much in taxes last year. However, in speaking of healthcare, she firmly supported Obamacare, because that helps the working class and the poor.

FEMALE: "I support Obamacare because it really helps a lot of low-income new immigrants. You know there are so many new immigrants who face a lot of financial hardship......even though I am not very happy with the Democrat on many issues, such as affirmative action, in general they are still better than the Republican Party for minorities." 
Politicization of identity emerges as one perceives their racial backgrounds with how politics works. As immigrants are exposed more to American society, some would start to assert social or group identities in politics. Thus, for many immigrants, their racial identities are a key element of how they conceptualize politics. A 37-year-old respondent from Honduras, who has lived in Los Angeles for 15 years, told us his perception of politics in the United States as a minority:

MODERATOR: How much do you feel that you have equal opportunities in this country?

MALE: I think this country is pretty great in terms of, you can do, and whatever you set your mind on. Maybe not whatever because I think that some people are more privileged and it's a lot easier for them to get into certain fields. But there's other things where, politics for example, is not the place where people want to see people of color. The current president [Donald Trump] calls out some of the female congresswomen, so the fact that some genders aren't even allowed in politics, which makes me realize that even if they are citizens of the U.S., they are females and they still have a hard time. I don't see how I would be welcomed as a minority. But like I said there's some fields and areas where it's going to be definitely a lot more difficult as a person of color.

Individuals in the highest level of Politicized Identity tend to well informed about and highly engaged in politics. Sufficient involvement in politics may act as a fair surrogate for racialized identity in providing more efficient modes of organizing political perceptions. People in this kind of collective identity that are engaged when people perceive themselves as self-conscious members in a power struggle on behalf of their group. I suggest that Politicized Identity forms through a sequence of correlated antecedent processes. A male discussant is a 47-year-old computer software engineer in Silicon Valley, and a strong Democrat. He told us about the way he perceived the Republican Party and Donald Trump:

"I didn't like Hilary Clinton at all. I still voted for the Democratic Party, because in the two-party system I didn't have other options. But I know I will always vote for Democrats. I believe that even if it was not Donald Trump, there will be another Republican candidate who just loves to play the race card. Deep in their heart, they just don't like minorities. Today they picked blacks, tomorrow they will pick Latinos, then they will pick Asians, or Muslims. Because that's what many conservative and ignorant Republicans like to hear."

There are some for whom politicized identity means identification as a Republican. James is a good example. James is a second-generation Chinese American who was born in San Francisco of parents who immigrated from Hong Kong. James is an owner of a bike shop in Culver City, 
CA. He is interested in politics and pays close attention to it as well. James is a strong Republican and a big fan of Donald Trump. James does not like the Democratic Party's policies, and he can complain at length about why their policies and ideology are naive. For example, he says,

MALE: What did Obama do over the last 8 years? Nothing! If Hilary Clinton became the President, she will basically follow Obama's policies. Obamacare made premium increased by 20 percent, and eventually insurance companies will pass on this cost to middle class Americans. Obamacare can't be a long-term policy; it will fail.

James makes no direct mention of ethnicity; he seems instead to identify as a middle-class American who will be hurt if Democrats violate what he takes to be the laws of economics. His politicized identity is as a member of an economic system.

\section{$5 \quad$ Data and method}

The data of this paper are drawn from in-depth qualitative interviews and surveys $(\mathrm{N}=221)$. Respondents were asked standard survey questions, but they were also given opportunities to express their open-ended opinions on those questions. The interviewers were instructed to probe extensively for further content on each of these open-ended questions. For example, when we asked respondents about their party identification, if they said "don't know," the interviewers would continue to ask them why they think they don't know. Both were conducted by UCLA undergraduate students.

Asians Americans and Latinos were 51 and 41 percent of the sample, with people of other racial backgrounds account for 8 percent. The average age across all groups are about 32 and female respondents account for slightly more than 50 percent. About 33 percent of all respondents were born in the U.S. and the average length of residence in the U.S. among the foreign born is 18 years. About 47 percent of immigrant respondents have been naturalized as US citizens. In addition, among them, Mexico and China together account for the majority of national origins.

Both the in-depth interviews and standard survey questions investigate immigrants' experiences as they are broadly exposed to American society. The survey relies heavily on qualitative interviews because they afford more opportunity to respond to flesh out the opinions. In particular, new arrivals might have difficulty in interpreting survey questions; as a result, they may shy away from responding to the survey questionnaire. Table 2 shows the questions that were used in the measurement of Party Conceptualization and Politicized Identity. 


\begin{tabular}{|l|}
\multicolumn{1}{c|}{ Party Conceptualization Questions } \\
\hline Do you know the differences between the Democratic and Republican Party? \\
Is there anything you like about the Democratic Party? \\
Is there anything you dislike about the Democratic Party? \\
Is there anything you like about the Republican Party? \\
Is there anything you dislike about the Republican Party? \\
How do you like/dislike Donald Trump? \\
How do you like/dislike Barack Obama? \\
How do you like/dislike Hillary Clinton? \\
\hline \multicolumn{1}{|c|}{ Politicized Identity Questions } \\
\hline How did you learn the differences between the Democratic and Republican Party? \\
How much do you feel you belong to this country and how did you develop this feeling? \\
How much do you feel that you have equal opportunities in this country as a minority? Any personal experiences? \\
How much do you think your ethnic group shares political interests with blacks? How did you learn that? \\
How much do you think your ethnic group shares political interest with whites? How did you learn about it? \\
How much do you think your ethnic group shares political interest with Asians/Latinos? How did you learn about it? \\
How did Obama's election as the president make you feel as being an immigrant? \\
How do you feel when Donald Trump criticized undocumented immigrants?
\end{tabular}

Table 2: Open-ended interview protocol

\subsection{Development of Party Conceptualization \& Politicized Identity}

The coding of the Party Conceptualization and Politicized Identity measures is based on the openended answers from these questions. On the basis of a holistic reading of these answers, the student coders classified each respondent as being in Levels 1, 2, 3, or 4 on Party Conceptualization, and separately as being in Levels 1, 2, 3, or 4 on Politicized Identity. The coding was done by three student coders. Instructions to Coders are given as appendix to the paper. The average inter-coder reliabilities between the three coders of the party conceptualization measure is . 80 , and the average reliability of the politicized identity is .77 . These reliabilities indicate a substantial agreement between coders. The scores given by the coders were averaged and rounded to a 4-point scale for summary statistics and ordered logistic regression analyses.

\subsection{Descriptive statistics}

Table 3 shows the proportion of respondents at each level of Party Conceptualization and Politicized Identity. The distributions of the Hispanic and Asian samples are quite similar. For the Party Conceptualization measure, about 18 percent of respondents in Level 1, 30 percent in Level 2, 43 percent of respondents in Level 3, and 9 percent in the Level 4. This distribution actually is quite close to the study conducted by Campbell et al. (1960). That is, most respondents are in the 
Level 2 and Level 3, and only a small proportion of respondents have sophisticated political knowledge that can use ideology to differentiate the parties, policies and candidates.

Scores on the Politicized Identity are somewhat higher than on the Party Conceptualization measure. Across both Hispanic and Asian samples, 16 percent of respondents in Level 1, 14 percent in Level 2, 45 percent in Level 3, and 25 percent in Level 4. Compared to the Party Conceptualization measure, there was a larger proportion of respondents in Politicized Identity. This disparity suggests that some Asian Americans and Latinos may have a broader and more abstract understanding of their identity than of the party system. In general, Hispanic and Asian respondents share similar patterns in the levels of the both measures.

\begin{tabular}{lcccccc}
\hline & & \multicolumn{2}{c}{ Party Conceptualization } & \multicolumn{2}{c}{ Politicized Identity } \\
Level 1 & Total Sample \% & Hispanic Sample \% & Asian Sample \% & Total Sample \% & Hispanic Sample \% & Asian Sample \% \\
Level 2 & 18 & 14 & 22 & 16 & 11 & 17 \\
Level 3 & 30 & 39 & 25 & 45 & 44 & 12 \\
Level 4 & 93 & 39 & 85 & 25 & 28 & 47 \\
\hline \hline
\end{tabular}

Table 3: Distribution of responses to the two measures
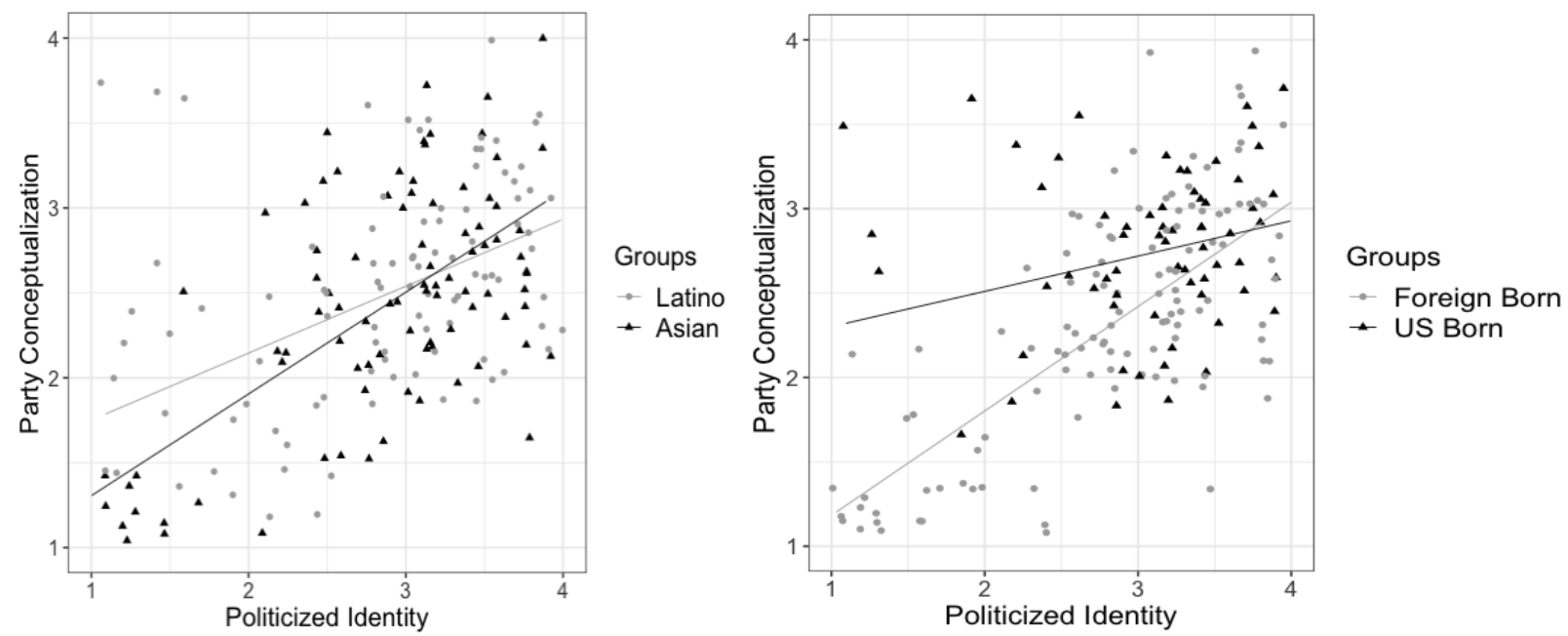

Figure 1: Scatterplot of Party Conceptualization and Politicized Identity

Figure 1 shows two bivariate relationships between Party Conceptualization and Politicized Identity. To further examine the relationship, subjects are also separated between Asian and Latino, as well as US-born and foreign-born. In general, Party Conceptualization and Politicized Identity tend to have a strong positive correlation. This relation is similar between Asian and Latino 
subjects. In Figure 1, the dark triangles represent Asian samples and the grey dots represent Latino samples. The least square lines highlight the positive correlation between the levels of Party Conceptualization and Politicized Identity. That is, $r=.69$ and $p$-value $<.001$ for Latino subjects and $r=.76$ and $\mathrm{p}<.001$ for Asian subjects. Therefore, high scorers on Politicized Identity tend to have higher levels of Party Conceptualization. Another plot on the right-hand side separates subjects into foreign-born and US-born. As we can see, the positive correlation between Party Conceptualization and Politicized Identity are still stronger among foreign-born citizens than their US-born counterparts.
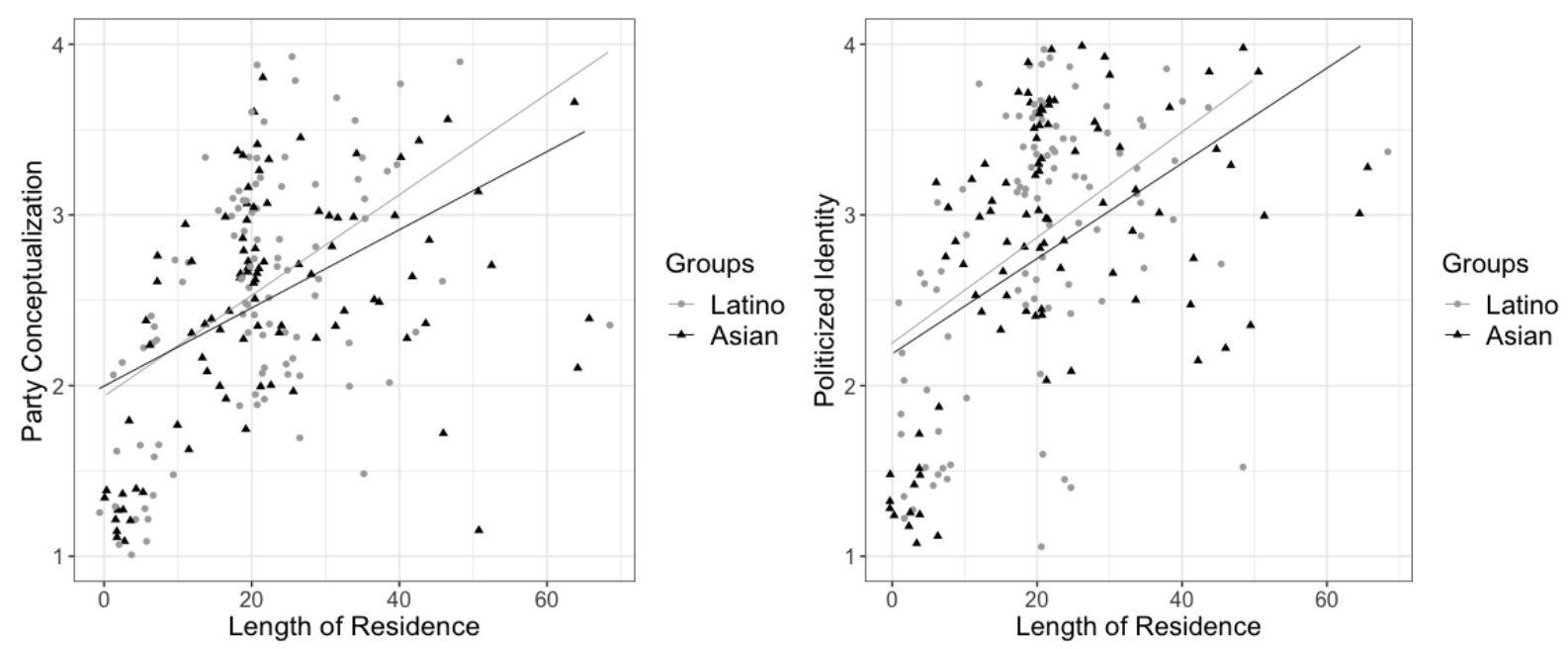

Figure 2: Party Conceptualization and Politicized Identity measures over time.

Figure 2 further suggests that the longer Asian American and Latino immigrants live in the U.S., the more likely they are to acquire a sophisticated understanding of parties and to form politicized ethnic identities. This pattern is highly similar between Latinos and Asian Americans, meaning that the more exposures or experiences to American politics, the more likely individuals tend to develop the party conceptualization and form politicized identities.

To further illuminate this relationship, we shall examine two measures of affective orientation toward politics, American Identity and Sense of Belonging. Both are measured on 10-point closed form scales. The American Identity question asks, "How much do you think of yourself as an American?" The Sense of Belonging item asks, "How much do you feel that you belong or don't belong to this country?" The score of 10 indicates the most American identity or have the strongest sense of belonging. Tables 4 and 5 suggest that the measures of American Identity and the Sense 
of Belonging have both affective components.

I noted earlier that scholars view party conceptualization as a mainly cognitive concept and politicized identity as a mainly affective one, while suggesting that the former may have an affective component and the latter a cognitive one. Tables 4 and 5 test this suggestion using the measures of American Identity and Sense of Belonging. Results show a clear ascending pattern among these measures. That is, when individuals have higher levels of Party Conceptualization and Politicized Identity, they tend to have higher levels of American identity and the Sense of Belonging.

\begin{tabular}{lccclccc}
\hline & \multicolumn{3}{c}{ American Identity } & \multicolumn{3}{c}{ American Identity } \\
Party Conceptualization & Low & Medium & High & Politicized Identity & Low & Medium & High \\
Level 1 & 17 & 1 & 5 & Level 1 & 15 & 1 & 4 \\
Level 2 & 2 & 6 & 13 & Level 2 & 2 & 1 & 3 \\
Level 3 & 2 & 7 & 36 & Level 3 & 2 & 6 & 28 \\
Level 4 & 0 & 1 & 11 & Level 4 & 2 & 6 & 31 \\
\hline \hline
\end{tabular}

Table 4: Distribution of American identity

\begin{tabular}{lccclccc}
\hline & \multicolumn{3}{c}{ Sense of Belonging } & & \multicolumn{3}{c}{ Sense of Belonging } \\
Party Conceptualization & Low & Medium & High & Politicized Identity & Low & Medium & High \\
Level 1 & 10 & 7 & 7 & Level 1 & 8 & 6 & 6 \\
Level 2 & 1 & 6 & 15 & Level 2 & 1 & 2 & 3 \\
Level 3 & 2 & 2 & 40 & Level 3 & 2 & 7 & 27 \\
Level 4 & 0 & 0 & 11 & Level 4 & 1 & 5 & 33 \\
\hline \hline
\end{tabular}

Table 5: Distribution of sense of belonging

Note: All entries in Tables $4 \& 5$ are in percentage

\section{The regression models}

As a preliminary to making the case that Party Conceptualization and Politicized Identity belong together in a dual-concept measure, I present simple ordered logistic regressions to separately examine the determinants of the two measures. In this analysis, I show that Party Conceptualization and Politicized Identity share numerous similarities in terms of multivariate relationship with key predictors.

\subsection{Variables}

I use two dependent variables and seven independent variables in the following regression analyses. The dependent variables are Party Conceptualization and Politicized Identity, which are 4-point categorical variables. The variation from low to high levels represents the ordering dimensions of 
these measures. The independent variable of political knowledge is a construct of 10 basic political knowledge items, e.g. what party Donald Trump belongs to, and which party favors affordable healthcare. Both the American Identity and Sense of Belonging variables are on a 10-point closed form scale, as described earlier. The variable of "News" asks respondents how often they follow American political news. I also added two new controlled variables. "Awareness" asks respondents how much they are concerned about the election outcome. "Political Discussion" asks respondents how often they discuss politics with their parents, friends, colleagues, etc.

\subsection{The models and results}

Ordered logistic regression was applied to analyze the relationship between dependent variables and independent variables. This model aims to test whether Party Conceptualization and Politicized Identity share a similar set of predictors, and what the major variables are that predict them. Table 6 includes 6 models; the first 3 models test the determinants of Party Conceptualization. Model 1 is a summary model that includes all respondents. Model 2 includes only Asian samples, and Model 3 includes only Hispanic samples. Model 3-6 test the determinants of Politicized Identity with aggregate, Asian and Hispanic samples. 


\begin{tabular}{|c|c|c|c|c|c|c|}
\hline & \multicolumn{3}{|c|}{ Party Conceptualization } & \multicolumn{3}{|c|}{ Polticized Identity } \\
\hline & (1) & $(2)$ & (3) & (4) & (5) & (6) \\
\hline & All & Asian & Hispanic & All & Asian & Hispanic \\
\hline Political Knowledge & $\begin{array}{l}0.201^{* * *} \\
(0.065)\end{array}$ & $\begin{array}{l}0.315^{* * * *} \\
(0.104)\end{array}$ & $\begin{array}{l}0.128 \\
(0.106)\end{array}$ & $\begin{array}{l}0.141^{* *} \\
(0.061)\end{array}$ & $\begin{array}{l}0.290^{* * * *} \\
(0.095)\end{array}$ & $\begin{array}{l}0.138 \\
(0.112)\end{array}$ \\
\hline Length of Residence & $\begin{array}{l}0.0607^{* * * *} \\
(0.015)\end{array}$ & $\begin{array}{l}0.0550^{* * * *} \\
(0.019)\end{array}$ & $\begin{array}{l}0.0642 * * \\
(0.032)\end{array}$ & $\begin{array}{l}0.0649 * * * * \\
(0.016)\end{array}$ & $\begin{array}{l}0.0667^{* * * *} \\
(0.020)\end{array}$ & $\begin{array}{l}0.0949 * * * \\
(0.034)\end{array}$ \\
\hline American Identity & $\begin{array}{l}0.287^{* * *} \\
(0.064)\end{array}$ & $\begin{array}{l}0.316^{* * * *} \\
(0.110)\end{array}$ & $\begin{array}{l}0.246^{* * *} \\
(0.101)\end{array}$ & $\begin{array}{l}0.179 * * * \\
(0.060)\end{array}$ & $\begin{array}{l}0.047 \\
(0.102)\end{array}$ & $\begin{array}{l}0.225^{* *} \\
(0.102)\end{array}$ \\
\hline Sense of Belonging & $\begin{array}{l}-0.053 \\
(0.059)\end{array}$ & $\begin{array}{l}-0.066 \\
(0.105)\end{array}$ & $\begin{array}{l}0.004 \\
(0.087)\end{array}$ & $\begin{array}{l}-0.053 \\
(0.057)\end{array}$ & $\begin{array}{l}0.070 \\
(0.097)\end{array}$ & $\begin{array}{l}0.001 \\
(0.092)\end{array}$ \\
\hline Awareness & $\begin{array}{l}-0.634 \\
(0.506)\end{array}$ & $\begin{array}{l}-0.187 \\
(0.746)\end{array}$ & $\begin{array}{l}-1.000 \\
(0.883)\end{array}$ & $\begin{array}{l}-0.245 \\
(0.476)\end{array}$ & $\begin{array}{l}-0.334 \\
(0.695)\end{array}$ & $\begin{array}{l}-0.197 \\
(0.903)\end{array}$ \\
\hline Political Discussion & $\begin{array}{l}0.038 \\
(0.121)\end{array}$ & $\begin{array}{l}-0.071 \\
(0.185)\end{array}$ & $\begin{array}{l}0.142 \\
(0.205)\end{array}$ & $\begin{array}{l}0.054 \\
(0.125)\end{array}$ & $\begin{array}{l}0.070 \\
(0.188)\end{array}$ & $\begin{array}{l}0.167 \\
(0.226)\end{array}$ \\
\hline News & $\begin{array}{l}-0.011 \\
(0.196)\end{array}$ & $\begin{array}{l}-0.164 \\
(0.291)\end{array}$ & $\begin{array}{l}-0.042 \\
(0.332)\end{array}$ & $\begin{array}{l}0.210 \\
(0.196)\end{array}$ & $\begin{array}{l}0.033 \\
(0.275)\end{array}$ & $\begin{array}{l}0.149 \\
(0.348)\end{array}$ \\
\hline English Media & $\begin{array}{l}-0.018 \\
(0.310)\end{array}$ & $\begin{array}{l}-0.073 \\
(0.501)\end{array}$ & $\begin{array}{l}-0.124 \\
(0.508)\end{array}$ & $\begin{array}{l}0.014 \\
(0.300)\end{array}$ & $\begin{array}{l}0.857^{*} \\
(0.484)\end{array}$ & $\begin{array}{l}-0.453 \\
(0.538)\end{array}$ \\
\hline Female & $\begin{array}{l}-0.295 \\
(0.289)\end{array}$ & $\begin{array}{l}-0.458 \\
(0.437)\end{array}$ & $\begin{array}{l}-0.089 \\
(0.456)\end{array}$ & $\begin{array}{l}0.369 \\
(0.282)\end{array}$ & $\begin{array}{l}-0.071 \\
(0.425)\end{array}$ & $\begin{array}{l}0.705 \\
(0.484)\end{array}$ \\
\hline Cut1 & $\begin{array}{l}1.552^{* *} \\
(0.671)\end{array}$ & $\begin{array}{l}2.225^{* *} \\
(0.979)\end{array}$ & $\begin{array}{l}0.727 \\
(1.122)\end{array}$ & $\begin{array}{l}1.525^{* *} \\
(0.638)\end{array}$ & $\begin{array}{l}2.735^{* * * *} \\
(0.966)\end{array}$ & $\begin{array}{l}1.185 \\
(1.132)\end{array}$ \\
\hline Cut2 & $\begin{array}{l}3.929 * * * \\
(0.731)\end{array}$ & $\begin{array}{l}4.452^{* * * *} \\
(1.085)\end{array}$ & $\begin{array}{l}3.715^{* * * *} \\
(1.215)\end{array}$ & $\begin{array}{l}2.829 * * * \\
(0.664)\end{array}$ & $\begin{array}{l}3.939 * * * \\
(1.010)\end{array}$ & $\begin{array}{l}3.646^{* * * *} \\
(1.231)\end{array}$ \\
\hline Cut3 & $\begin{array}{l}6.916^{* * * *} \\
(0.811)\end{array}$ & $\begin{array}{l}7.842^{* * * *} \\
(1.218)\end{array}$ & $\begin{array}{l}6.350 * * * \\
(1.309)\end{array}$ & $\begin{array}{l}5.464 * * * \\
(0.735)\end{array}$ & $\begin{array}{l}6.923 * * * \\
(1.148)\end{array}$ & $\begin{array}{l}6.711^{* * *} \\
(1.379)\end{array}$ \\
\hline $\mathrm{N}$ & 202 & 101 & 80 & 202 & 101 & 80 \\
\hline
\end{tabular}

Table 6: Determinants of Party Conceptualization and Politicized Identity

Regression analysis in Table 6 demonstrates that Party Conceptualization and Politicized Identity have similar relationships with key predictors. As we can see, political knowledge, length of residence and American identity are statistically significant. These patterns are consistent across all models in Table 6. Both Asian and Latino samples also share similar patterns. These patterns lend confidence to the idea that the broader and more abstract forms of thought that both Party Conceptualization and Politicized Identity aim to capture are due to a common set of causes, namely, lived experience in the United States and exposure to politics. Note, however, that the Sense of Belonging variable is not statistically significant in these models. The reason for this is two-fold: 1) the sense of belonging comes with a fair amount of variance; 2) the sense of belonging, American identity and length of residence share a moderate amount of covariances. As a result, including them together in a model results multicollinearity. To handle this issue, we will need to correct the error variances using SEM, which I will discuss in detail later. 
In addition, the variables Political Discussion, News, and English Media Consumption are not statistically significant. This is most likely because their effects are mediated by the Knowledge variable. That is, political discussion, news, and English media cause Knowledge, and more knowledge, in turn, causes broader and more abstract thinking as measured by Party Conceptualization and Politicized identity. But with Knowledge in the regression, the effects of the more distal variables are absorbed in the Knowledge variable and not directly visible. In addition, the ambiguous nature of these variables poses important empirical problems. In part, because these variables are elusive in the sense that it is difficult for individuals to pinpoint how often they discuss politics with friends, colleagues, or family members, and how much they actually pay attention to English media. This, in turn, means that many respondents simply gave ambiguous survey answers such as "often." As a result, these variables usually vary little themselves, share little covariances with other variables, and ultimately have difficulty producing statistically significant results in regression analysis.

\section{$7 \quad$ A MIMIC model and political conceptualization}

The regression models reported in Table 6 show that Party Conceptualization and Politicized Identity share a set of common predictors. This suggests that Party Conceptualization and Politicized Identity might form a single latent factor. Despite the fact that this latent variable is a hypothetical construct and not directly observed, it has operational implications for structural relationships among measured variables. That is, if Party Conceptualization and Politicized Identity are measured separately but part of the same concept - namely, a propensity for broad and abstract thinking - we should expect to see both measures have equivalent and statistically significant factor loadings that are influenced by a common latent factor. Since it is impossible to test a latent variable directly in a regression model, I will apply a MIMIC model, which consists of multiple indicators and multiple causes of a single latent variable (F1) (Joreskog \& Goldberger, 1975).

Figure 3 is a diagram of a MIMIC model, in which Political Conceptualization is a latent variable and a dependent variable that is constructed by Party Conceptualization and Politicized Identity, which is also predicted by a set of measured predictors. All independent variables on the left of the diagram are the predictors in the model, and all of their error variances are allowed to freely correlate among themselves, as they do in regression models such as in Table 6. The 
variances and covariance of all independent variables are all free parameters. The variables on the right of the path diagram are two measured indicators-Party Conceptualization and Politicized Identity. The dependent variable is a latent variable (F1) representing what Party Conceptualization and Politicized Identity share in common, which explains the correlation between these variables, but is not explained in separate regressions. However, in this model a given predictor, say, political knowledge has only 1 effect, its effect on Political Conceptualization (F1). So instead of 2 separate coefficients, there is one to estimate and interpret. Of course, as in the regression model in Table 6, any predictor also affects the dependent variables Party Conceptualization and Politicized Identity, but the effect is indirect. Thus, if the MIMIC model is consistent with the regression model, we should expect to see the factor loadings of measured variables on the left of the path diagram are somewhat close to those in Table 6 in terms of magnitude, direction and statistics significance. And the product of factor loadings of Party Conceptualization and Politicized Identity should account for the correlation between them.

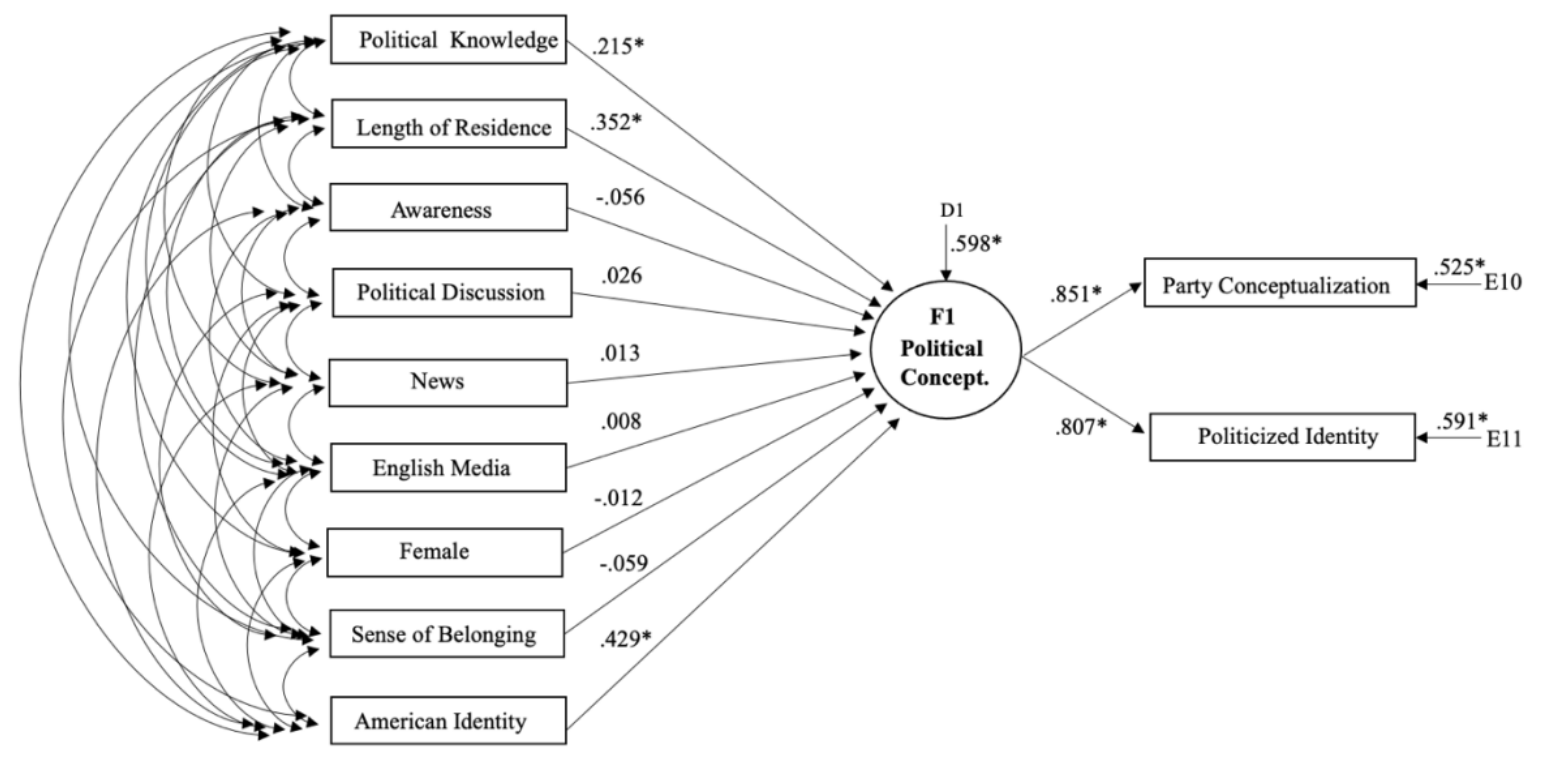

Statistics significant at the $5 \%$ level are marked with *

Figure 3: A MIMIC model of Party Conceptualization and Politicized Identity

The result of the MIMIC model shows that Political Conceptualization was effectively predicted by a set of variables, and it also determined Party Conceptualization and Politicized Identity. More importantly, the latent factor Political Conceptualization successfully explains most shared variance between Party Conceptualization and Politicized Identity as evident by high 
standardized factor loadings .851 and $.807(p<.05)$ after correcting the error variances. The correlations between the predictor and criterion (Party Conceptualization and Politicized Identity) variables are also precisely explained by the model, with the largest standardized residual correlation being .077, which is still close to zero (See appendix). This means that the two-concepts are distinctive measures. Moreover, from the other end of the spectrum, political knowledge, length of residence and American identity are statistically significant predictors for the latent factor (F1). In terms of values, coefficient direction and statistically significance, they are roughly consistent with those reported in the regression model in Table 6. This suggests that these variables are key predictors for Political Conceptualization as immigrants live in the United States over time, and they ultimately indirectly shape both Party Conceptualization and Politicized Identity.

The Chi-Square test statistic that is derived from maximum likelihood (ML) estimator is 8.63 based on 8 degrees of freedom, which yields a p-value $=.374$. This indicates that the sample covariance structure is highly equivalent to the model-implied covariance structure. Thus, the model is an extremely plausible one, and we cannot reject the null hypothesis. Moreover, other goodness-of-fit indices lend us extra confidence. Bentler-Bonett's (1980) normed fit index (NFI) is .986, Bentler's (1990) CFI is 0.99 and RMSEA is 0.02. Based on the MIMIC model, we can see that political knowledge, the length of history in the U.S., exposure to politics, etc., can indirectly shape Party Conceptualization and Politicized Identity formation. For immigrant Americans, coming to understand who they are, how American politics works, and how they fit into American politics is all part of the same learning process. Nonetheless, the regression result needs to be further examined, because the regression models do not correct for error variances.

\section{Measurement in Party Conceptualization and Politicized Identity}

To examine the properties of the dual-concept measure we must consider the latent structure of both respondents' level of Party Conceptualization and Politicized Identity formation. As argued earlier, post-migration experience among immigrants may consist of two general currents of stimuli: Cognitive stimuli and emotional stimuli. Each current may contribute to common political conceptualization experiences in American politics. Such learning experiences eventually indirectly affect Party Conceptualization and Politicized Identity formation.

Thus far, qualitative interview data strongly suggest that the concepts of Party Conceptualization and Politicized Identity are two distinct measures that each capture a common 
tendency toward broad and abstract thinking among Asian Americans and Latinos. A natural question after considering the qualitative interviews is how well quantitative data are in accord with them, and how we can validate these measures statistically. Political Conceptualization is a multidimensional political learning outcome; it might consist of components that are positively correlated. It is also true that measurement of Political Conceptualization has been plagued by measurement errors (Smith, 1980). To mitigate these concerns, this section further examines whether a common latent factor, Political Conceptualization, captures these two concepts, and how reliable we should expect the measurement to be. For this analysis, I employ SEM to test the underlying structural relationship between cognitive and emotional stimulus variables, and the latent variables constructed by them.

My hypothesis is that there is a common latent variable behind the two measured variables. SEM approach to confirmatory factor analysis allows us to test not only how many factors might exist, but also which variables might be good indicators of a given factor, and which variables cannot be indicators of a factor. As compared to the traditional regression model, an appropriate latent variable model can yield a basis for correct inference with measured variables per construct while providing more information, since a measurement model may be contained within a complete structural model. That is, a measurement model provides information on the factor loadings that relate the indicators and the latent constructs as well as on the variances and covariances of measurement errors and of the constructs. Therefore, the task of the following analysis is to test whether such as theory might be correct.

As noted in Figure 4, each variable was included as an indicator of a particular factor. Altogether there are 8 measured variables, leading to an $8 \times 8$ covariance matrix that is to be modeled. The complete set of equations for the model thus includes the first 8 measurement equations that express the measured variables in terms of factors and residuals. Using these variables, I create a SEM model to account for that relationship. In this SEM model, I include cognitive measured indicators and emotional measured indicators to construct two latent factors: Cognitive stimulus factor and emotional stimulus factor. The cognitive stimulus factor (F1) is constructed by four indicators: political knowledge, political interest, political discussion, and news. The emotional stimulus factor (F2) is constructed by American identity and the sense of belonging. The two factors F1 and F2 are presumed to generate the correlations among the 
variables: political knowledge, political interest, awareness, English media consumption, American identity and the sense of belonging.

Moreover, I also create a third factor-Political Conceptualization factor (F3) — to capture the common effect of both cognitive and emotional stimulus factors. This latent factor is constructed by Party Conceptualization and Politicized Identity and, simultaneously, it is also predicted by cognitive stimulus factor (F1) and emotional stimulus factor (F2). Since Political Conceptualization (F3) is a common factor between F1 and F2, it is presumed to generate the correlations among Party Conceptualization and Politicized Identity.

The analysis was conducted using statistical software EQS. As Figure 4 shows, all parameters of factor loadings are free to be estimated, except for the ones connecting cognitive stimulus factor (F1) and Political Conceptualization (F3), which is fixed at 1.0, and variances of F1 and F2 are fixed to be 1.0 for the identification purpose. Moreover, parameter estimates of dependent variables always come with unique or error variances $E_{i}$. Likewise, when factors are used as dependent variables, the parameter estimates always come with factor residual variances $D_{i}$.

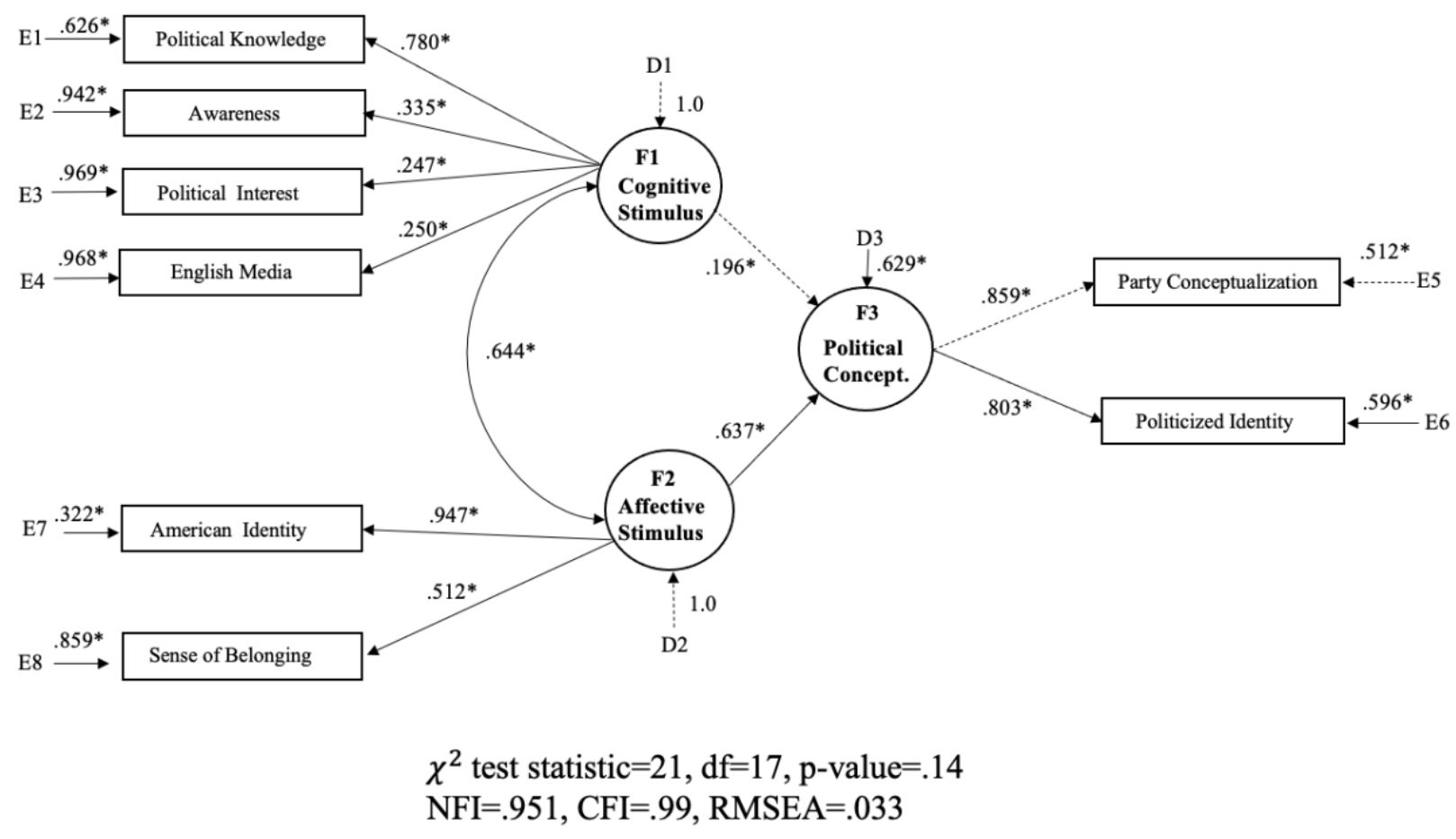


Figure 4: A SEM model path diagram

Note: Statistics significant at the 5\% level are marked with *.

Dash line means the variable is fixed at 1.0 for identification purpose

Path diagrams such as Figure 4 are used to create equations in a rather direct manner, in which 8 variables were selected to represent 3 latent constructs. The factor loadings, error variances and factor residual variances reported in Figure 4 are standardized. Among those indicators which construct cognitive stimulus factors, only political knowledge has a high factor loading .78, other indicators tend to have low ones. These low factor loadings are due to unreliability in the measures, which is evident in their large error variances. That is, individuals' chronic exposure to English media and self-report interest in politics would not be a reliable predictor for the cognitive stimulus factor (F1). In contrast, American identity and the sense of belonging tend to have high factor loadings on emotional stimulus factor (F2). This implies that identity variables are strongly correlated.

The critical substantive questions of interest lie in four key parameters: The factor loadings between F1, F2, and F3, as well as the factor loadings between F3 and Party Conceptualization, and between F3 and Politicized Identity. Note that I choose to hold the variance of F1 and F2 fixed at 1.0 for identification purposes. Such constraints are not used in general, but they are needed here to reduce the number of parameters to be estimated. The interrelation between F1 and F2 is .644, meaning that cognitive and emotional stimuli are moderately correlated. The factor loading between Politicized Identity (F2) and Political Conceptualization (F3) is .637, which is also moderately high, indicating that emotional stimulus factor can effectively predict Political Conceptualization. In contrast, the factor loading between cognitive stimulus factor (F1) and Political Conceptualization factor (F3) is .196 and factor residual variance is small .629. This suggests that the effect of cognitive stimulus factor (F1) and Political Conceptualization (F3) are not highly related. By and large, emotional stimuli, such as the sense of belonging, American identity and Politicized Identity offer cumulative and steady support for nurturing overall Political Conceptualization. Most importantly, Party Conceptualization and Politicized Identity are both excellent indicators of overall Political Conceptualization. Yet, despite being highly correlated, they are not identical; they do measure something separate from the factor. This lends us the statistical evidence that Party Conceptualization and Politicized Identity are two distinct concepts. (A review of goodness-of-fit statistics is contained in the paper's appendix) 
In substantive terms, the model's results show that individuals vary in their propensity to think about politics in narrow and concrete terms versus abstract and general terms, with this propensity manifesting itself in thinking about both parties and campaigns and about one's identity in relation to the political system. This propensity is itself due in small degree to attention to news and information about politics, and to large degree to the development of affective attachment to American politics and society. There was reason to anticipate that both affective and cognitive factors would contribute to broader and more abstract thinking, but the greater contribution of affect was not anticipated. It therefore stands as one of the more important findings of this study, and one that should be replicated on other data and other subjects.

\section{Discussion \& conclusion}

Campbell et al. (1960) and Smith (1980) maintained that the levels of political conceptualization were primarily determined by cognitive abilities. They assumed that cognitive abilities are mainly permanent traits, and that to the extent that they influence the levels of conceptualization, they should be fairly stable over time. Moreover, past studies have documented that cognitive limitations are the basis for ideological sophistication, because low cognitive respondents might not be able to use ideological language in their responses (Nie, Verba, \& Petrocik, 1976; Smith, 1980).

These studies used a single measure of conceptualization, one that focused on parties and candidates. This paper extends the study of political conceptualization by measuring it within a second domain, the conceptualization of identity in relation to the political system for immigrant populations. My results show that individuals conceptualize similarly within each domain and that the determinants of conceptualization are also similar in each domain. Going further, I show that a model that posits a latent dual-concept measure of political conceptualization fits data on the determinants of party conceptualization, politicized identity and their relationship to one another. Thus while party conceptualization and politicized identity can be measured separately, they are in practice closely correlated. People who have a concrete and narrow understanding of the party system have a similarly narrow and concrete understanding of how they relate to that system. Together these narratives help constitute a novel paradigm for the study of political learning and socialization. 
Perhaps more importantly, I have shown that Party Conceptualization and Politicized Identity are both predicted by both cognitive and emotional factors. Cognitive processes among immigrants may be constrained by language, but my results suggest that such individuals can still learn about the parties and politics on the basis of daily social experiences. In other words, experience-based political conceptualization can take the lead in political socialization, with emotional stimuli playing a critical role in political learning (Brader, 2006; Damasio, 1994; Huddy, 2001; Huddy, Mason, \& Aaroe, 2015a; Uhlaner \& Garcia, 2005). This finding echoes Sears et al.'s (2016) research on Latino partisanship acquisition that Latinos tend to have latent partisan preference toward Democrat even when they have little information about the parties. By and large, party conceptualization and politicization of identity embedded in lived experiences in the United States tend to increase the consistency and coherence of political attitudes in the parties, policies, and candidates. As Asian and Latino immigrants live in the United States longer and acquire more exposure to American politics, the growth of political conceptions leads to greater consistency in preference. 


\section{References}

Alvarez, R. M., \& Garcia Bedolla, L. (2003). The foundations of Latino voter partisanship: evidence from the 2000 election. Journal of Politics, 65(1), 31-49.

Bakker, B., Schumacher, G., \& Rooduijn, M. (2021). Hot politics? Affective responses to political rhetoric. American Political Science Review, 115(1), 150-164.

Barreto, M. A., \& Segura, G. M. (2014). Latino America: How American's most dynamic population is poised to transform the politics of the nation. New York: PublicAffairs.

Bentler, P. (1990). Comparative fit indexes in structural models. Psychological Bulletin, 107, 238246.

Bentler, P., \& Bonett, D. G. (1980). Significance tests and goodness of fit in the analysis of covariance structures. Psychological Bulletin, 88, 588-606.

Bobo, L., \& Gilliam, F. D. (1990). Race, sociopolitical participation and black empowerment. American Political Science Review, 84(2), 377-393.

Brader, T. (2006). Campaigning for Hearts and Minds. Chicago: The University of Chicago Press.

Campbell, A., Converse, P., Miller, W., \& Stokes, D. (1960). The American Voter. New York: John Wiley \& Sons, Inc.

Campbell, A., Converse, P., Miller, W., \& Stokes, D. (1966). The American Voter. New York: John Wiley \& Sons, Inc.

Citrin, J., \& Sears, D. O. (2014). American identity and the politics of multiculturalism. New York, NY: Cambridge University Press.

Crocker, J., \& Luhtanen, R. (1990). Collective self-esteem and ingroup bias. Journal of Personality and Social Psychology, 58, 60-67.

Dacher, K., \& Gross, J. J. (1999). Functional accounts of emotion. Cognition \& Emotion, 13(5), 467-480.

Damasio, A. R. (1994). Descartes'Error: Emotion, Reason, and the Human Brain. New York: Putnam.

Dawson, M. C. (2001). Black visions: the roots of contemporary African-American political ideologies. Chicago: University of Chicago Press.

Downs, A. (1957). An Economic Theory of Democracy. New York: Harper.

Garcia Bedolla, L. (2005). Fluid borders: Latino power, identity, and politics in Los Angeles. Berkeley: University of California Press.

Green, D., Palmquis, B., \& Schickler, E. (2002). Partisan Hearts and Minds: Political Parties and the Social Identities of Voters. New Haven: Yale University Press. 
Hajnal, Z., \& Lee, T. (2006). Out of Line: Immigration and Party Identification among Latinos and Asian Americans. In T. Lee, S. K. Ramakrishnan, \& R. Ramírez (Eds.), Transforming Politics, Transforming America: The politics and Civic Incorporation of Immigrants in the United States. Charlottesville: University of Virginia Press.

Hajnal, Z., \& Lee, T. (2011). Why Americans Don't Join the Party: Race, Immigration, and the Failure (of Political Parties) to Engage the Electorate. Princeton: Princeton University Press.

Huddy, L. (2001). From social to political identity: a critical examination of social identity theory. Political Psychology, 22(1), 127-156.

Huddy, L., Mason, L., \& Aaroe, L. (2015a). Expressive Partisanship: Campaign Involvement, Political Emotion, and Partisan Identity. The American Political Science Review, 109(No. $1)$.

Huddy, L., Mason, L., \& Aaroe, L. (2015b). Expressive partisanship: campaign involvement, political emotion, and partisan identity. American Political Science Review, 109(1). doi:10.1017/S0003055414000604

Huddy, L., Mason, L., \& Horwitz, S. N. (2016). Political identity convergence: on being Latino, becoming a Democrat, and getting active. RSF: The Russell Sage Foundation Journal of the Social Sciences, 2(3), 205-228. doi:https://doi.org/10.7758/rsf.2016.2.3.11

Joreskog, K., \& Goldberger, A. S. (1975). Estimation of a model with multiple indicators and multiple causes of a single latent variable. Journal of the American Statistical Association, 70(351), 631-639.

Junn, J. (2006a). Mobilizing Group consciousness: When Does Ethnicity Have Political Consequences? . In T. Lee, S. K. Ramakrishnan, \& R. Ramírez (Eds.), Transforming Politics, Transforming America: The Political and Civic Incorporation of Immigrants in the United States. Charlottesville: University of Virgina Press.

Junn, J. (2006b). Mobilizing Group consciousness: When Does Ethnicity Have Political Consequences? In T. Lee, S. K. Ramakrishnan, \& R. Ramírez (Eds.), Transforming Politics, Transforming America: The Political and Civic Incorporation of Immigrants in the United States. Charlottesville: University of Virgina Press.

Junn, J., \& Masuoka, N. (2008). Identities in context: politicized racial group consciousness among Asian American and Latino youth. Applied Development Science, 12(2), 93-101. doi:10.1080/10888690801997234

Lau, R. R. (1986). Political Schemata, Candidate Evaluations, and Voting Behavior. In R. R. Lau \& D. O. Sears (Eds.), Political Cognition: The 19th Annual Carnegie Symposium on Cognition. Hillsdale: Lawrence Erlbaum Associate, Inc.

Lewis-Beck, M. S., Jacoby, W. G., Norpoth, H., \& Weisberg, H. E. (2008). The American Voter Revisited. Ann Arbor: The University of Michigan.

Lien, P.-t. (1994). Ethnicity and political participation: a comparison between Asian and Mexican Americans. Political Behavior, 16(6), 874-900. 
Lien, P.-t., Conway, M., \& Wong, J. S. (2003). The contours and sources of ethnic identity choices among Asian Americans. Social Science Quarterly, 84(2), 461-481.

Miller, J. M., \& Peterson, D. A. M. (2004). Theoretical and empirical implications of attitude strength. Journal of Politics, 66(3, August), 847-867.

Nie, N., Verba, S., \& Petrocik, J. R. (1976). The Changing American Voter. Cambridge MA: Harvard University Press.

Parker, C. S., \& Barreto, M. A. (2013). Change They Can't Believe In: The Tea Party and Reactionary Politics in America. Princeton: Princeton University.

Sanchez, G. R. (2006). The role of group consciousness in political participation among Latinos in the United States. American Politics Research, 34(4), 427-450.

Sears, D. O., Danbold, F., \& Zavala, V. (2016). Incorporation of Latino Immigrants into the American Party System. RSF: The Russell Sage Foundation Journal of the Social Sciences, 2(3), 183-204.

Segura, G. M. (2013). Behavorial and attitudinal components of immigrant political incorporation. In J. Hochschild, J. Chattopadhyay, C. Gay, \& M. Jones-Correa (Eds.), Outsiders No More? Models of Immigrant Political Incorporation. New York: Oxford University Press.

Sidanius, J., \& Pratto, F. (1999). Social Dominance: An Intergroup Theory of Social Hierarchy and Oppression. New York: Cambridge University Press.

Simon, B., \& Klandermans, B. (2001). Politicized collective identity: a social psychological analysis. American Psychologist, 56(4), 319-331. doi:https://doi.org/10.1037/0003$\underline{\text { 066X.56.4.319 }}$

Smith, E. R. A. N. (1980). The Levels of Conceptualization: False Measures of Ideological Sophistication. American Political Science Review, 74, 685-696.

Tajfel, H., \& Turner, J. C. (1986). The social identity theory of intergroup behaviour. In S. Worchel \& W. G. Austin (Eds.), Psychology of intergroup relations. Chicago: Nelson-Hall.

Tate, K. (1994). From Protest to Politics. New York: Russell Sage Foundation.

Turner, J. C., \& Reynolds, K. J. (2003). The Social Identity Perspective. In R. Brown \& S. Gaertner (Eds.), Blackwell Handbook of Social Psychology: Intergroup Processess. Oxford: Blackwell.

Uhlaner, C. J., \& Garcia, C. (2005). Learning which party fits: experience, ethnic identity, and the demographic foundation of Latino party identification. In G. M. Segura \& S. Bowler (Eds.), Diversity in Democracy: Minority Representation in the United States. Charlottesville: University of Virginia Press.

West, E. A., \& Iyengar, S. (2020). Partisanship as a social identity: implication for polarization. Political Behavior. doi:https://doi.org/10.1007/s11109-020-09637-y

Wong, J., Ramakrishnan, S. K., Lee, T., \& Junn, J. (2011). Asian American Political Participation: Emerging Constituents and Their Political Identities. New York: Russell Sage Foundation. 
Zaller, J. (1992). The nature and origins of mass opinion. New York: Cambridge University Press.

Zheng, B. Q. (2019). The Patterns of Asian Americans' Partisan Choice: Policy Preferences and Racial Consciousness. Social Science Quarterly. doi:10.1111/ssqu.12652

\section{Appendix}

\section{Data and Sampling Method}

The original data presented in this study were collected in collaboration with undergraduate students at the author's university in 2019. Immigrant participants, particularly new immigrant participants are not easy to find. Thus, we used snowball sampling method to recruit potential participants, which doesn't have the probability in random selection. In 2019, we conducted 3045-minute-long interviews with immigrant and racial/ethnic minorities in California. The interviews were conducted in English or the respondents' native languages. Prior to each interview and survey, facilitators were trained using the protocol the author developed. In this study, we didn't compensate participants, because participation in this research is completely voluntary. Ethical approval for this research was obtained from Office of the Human Research Protections of UCLA.

\section{Discussion Protocol}

\section{Introduction of Moderator and Objectives of Study}

$\mathrm{Hi}$, I'm [ ] and I'm a student at [the author's university]. I'm part of a team doing immigrants' political socialization project for the Political Science Department. It's part of our study to increase public understanding of how immigrants learn about American politics and acquire partisanship. Would you have about 30 minutes to answer an anonymous survey? A few minutes of your time would help us a lot.

\section{Organization of Session}

[We detail the consent form before beginning] 
This interview is anonymous. Do you agree to participate in this interview? If you do, may I record you, or do you want me to just write out your comments.

\section{Descriptive Data}

The descriptive data presented in Figure A.1 are based on 221 respondents who participated in the interviews. Figure A. 1 shows, the major national origins of respondents. Among Latino group, most respondents are from Mexico, Guatemala and El Salvador. Among Asian immigrants, most respondents are from China, India, Taiwan, the Philippines, South Korea, Pakistan and Vietnam.

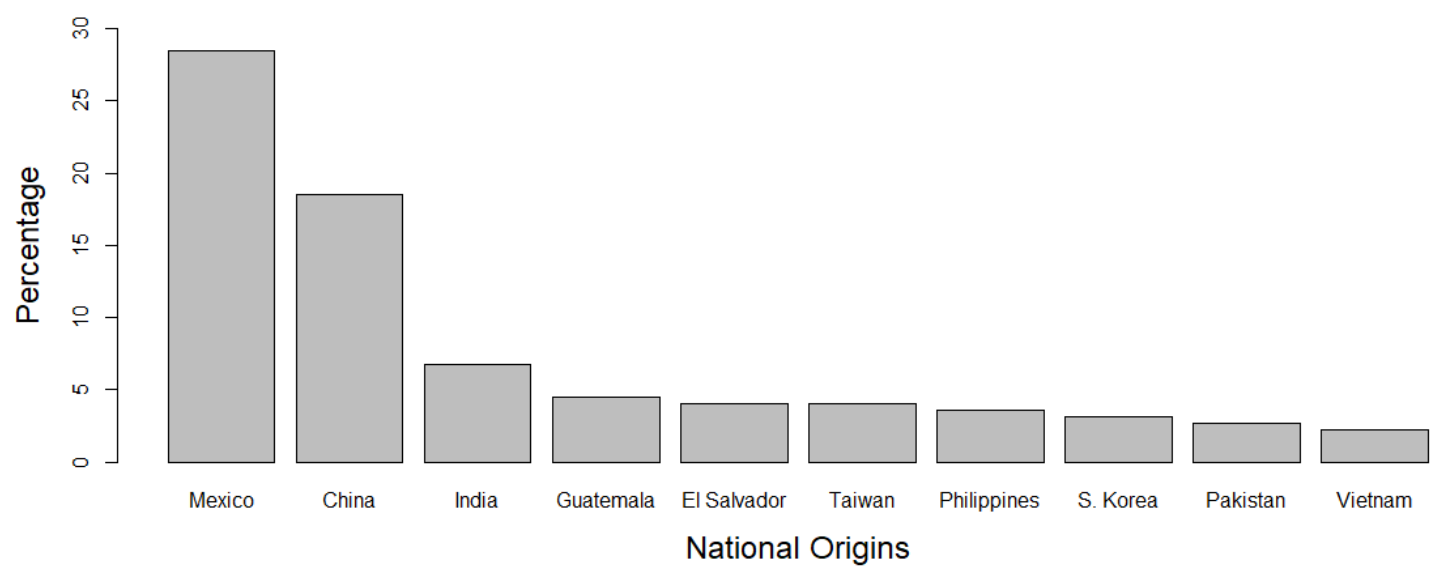

Figure A.1: Major national origins of respondents

\section{Basic demographic characteristics}

Table A.1 shows the basic demographic characteristics of Asian American and Latino groups. In general, the demographic characteristics of these two groups are very similar. The average ages for Asians and Latinos are 31- and 33-year-old. 52 percent of Asian sample and 62 percent of Latino sample are female. 33 percent of both Asian and Latino samples were born in the United States. Among those foreign-born, the average years of residence in the United States are 17 and 19 years respectively for Asians and Latinos. 52 percent of Asian sample and 43 percent of Latino sample are U.S. citizens. In terms of partisanship, 64 percent of Asian sample and 69 percent of Latino sample identify as Democrats. 


\begin{tabular}{lcc}
\hline & Asians & Latinos \\
Age (average) & 31 & 33 \\
\% Female & 52 & 62 \\
\% Born in U.S. & 33 & 33 \\
If foreign born: Years in U.S. & 17 & 19 \\
\% U.S citizen among foreign born & 52 & 43 \\
\% Democrat & 64 & 69 \\
$\mathrm{~N}$ & 108 & 89 \\
\hline \hline
\end{tabular}

Table A.1: Basic demographic characteristics

Table A.1 shows the basic demographic characteristics of Asian American and Latino groups. In general, the demographic characteristics of these two groups are very similar. The average ages for Asians and Latinos are 31- and 33-year-old. 52 percent of Asian sample and 62 percent of Latino sample are female. 33 percent of both Asian and Latino samples were born in the United States. Among those foreign-born, the average years of residence in the United States are 17 and 19 years respectively for Asians and Latinos. 52 percent of Asian sample and 43 percent of Latino sample are U.S. citizens. In terms of partisanship, 64 percent of Asian sample and 69 percent of Latino sample identify as Democrats.

\section{Descriptive statistics of major variables}

\begin{tabular}{lccccc}
\hline & N & Mean & SD & Min & Max \\
Political Knolwedge & 221 & 7.44 & 2.77 & 0 & 10 \\
Political Interest & 221 & 0.14 & 0.34 & 0 & 1 \\
Political Discussion & 220 & 2.44 & 1.29 & 1 & 6 \\
News & 220 & 2.5 & 0.87 & 1 & 4 \\
Sense of Belonging & 220 & 6.91 & 2.93 & 0 & 10 \\
American Identity & 219 & 6.81 & 3.44 & 0 & 10 \\
Party Identitification & 218 & 2.83 & 1.48 & 1 & 7 \\
Partisan Strength & 218 & 1.51 & 1.12 & 0 & 3 \\
Awareness & 207 & 0.68 & 0.31 & 0 & 1 \\
Female & 221 & 0.54 & 0.49 & 0 & 1 \\
\hline \hline
\end{tabular}

Table A.2: Descriptive statistics of major variables

\section{Instructions to Coders}


Each respondent should be assigned two numerical values, one that indicates her Level of Party Conceptualization and another that indicates her Level of Politicized Identity. These measurements should be based on the coding rules described below.

Measurements of Party Conceptualization should be made from responses to a set of eight questions that ask about the political parties, Donald Trump, Barack Obama, and Hillary Clinton. Measurements of Politicized Identity should be made from a separate set of eight questions that mainly focus on groups in American politics.

\section{Party Conceptualization}

\section{Level 1: No issue content}

Subject seems unable to discriminate between the Democratic and Republican Party, or the meaning of liberal and conservative. Subject does not comment on any national political issue or public debate. A subject who comments on a non-partisan issue or irritation could still be classified at this level. Those who fail to comment on parties and candidates in politically meaningful ways or show indifference to politics should be included in this category.

Example:

"I don't have any interest in politics, and I can't think of a thing about the parties."

'I don't know any of them to be honest. I don't know what is this and what is that. I've been here for 8 years, and 6 years I was a student. I didn't even have a TV or looked at the news or anything. So I'm far away from all that to be honest."

\section{Level 2: Nature of the times}

Responses are based on the conditions of the country, the general success or failure of the country's leadership, or any nebulous mood or feeling. If a party is mentioned, it is only to blame or credit the party for national conditions. Respondents in this category generally do not otherwise mention parties, issues, or ideology. Respondents might have specific comments on the personalities, traits 
or characteristics of candidates, parties, or ideologies, but those comments focus on the goodness or badness of the times rather than any policy or value.

\section{Example:}

"Like regardless of what his policies were, his figure as the President [Obama] did that job well and I think that's one of the most important things you can do in office because realistically you don't have like a ton of influence over policy but like, the way you come off to the world is how we're going to be treated by other countries so I think he just did that well. He didn't make U.S. look like, stupid."

\section{Level 3: Group benefits}

Respondents make simple evaluations of political objects in terms of visible groupings. Parties and candidates are seen as good or bad for particular groups, or as having a natural affinity or repulsion for particular groups, but there is little or no ideological or policy justification for their views.

\section{Example:}

"The Democratic Party is more favorable to minorities and immigrants." "... the Republican Party is hostile to the working class."

\section{Level 4: Policy and ideology}

Respondents evaluate political objects in terms of policies and ideology. They either mention the liberal-conservative continuum in a meaningful way or cite policy preferences that are consistent with their party identifications. The most sophisticated respondents demonstrate partisan loyalty, political knowledge and concern for policies and ideology, but such high levels of conceptualization are not necessary for classification in Level 4. Respondents need only to be generally aware of general American politics and policies and make coherent references to party policies and ideologies.

Example:

"I think the Republican is more conservative; they are not so subject to radical change." 
"I like the Democratic Party because I like their liberalness."

\section{Politicized Identity}

\section{Level 1: Foreigners in America}

Individuals lack a social or racial identity consciousness attached to the United States. They see themselves as foreigners in a mass of undifferentiated Americans. Their concept of social identity tends to be rooted in their country of origin.

Example:

"People in the United States have too many racial backgrounds, and are too complicated. Other than white and black people, I don't know how to tell the differences between Mexican, Middle Eastern people, and others. To me they look basically the same."

"We still have no idea how long we will stay in the United States. If the economy is bad, we might move back to China, who knows. We have some friends who have moved back to China, and they did much better there than they did here. It is a lot easier to make money in China nowadays. But more of our friends chose to stay in here simply for the sake of the children. Growing up in the United States is much better than in China, because they have more opportunities here. Unlike us, we don't know English, we don't have any opportunities."

\section{Level 2: Recognition of Multiethnic America}

Subjects see themselves as members of an ethnic group like many others in the United States. This may include a perception of conflict between their group and other groups. They may also recognize a connection between ethnicity and politics, but only vaguely. For example, they may see one of the parties as better for their group or other groups, but cannot explain why.

Example:

"I was told that the Democratic Party is the party that represents the interest for the poor. Almost all of my friends and neighbors always vote for Democrats, and so do I. We are immigrants. We work hard but don't make a lot of money. Democrats are the party that is more friendly to us, for example, Obamacare really helped me and my friends a lot. This is all I know."

\section{Level 3: Group-based party politics}


Subjects in the category of issue-based group politics perceive a clear link between parties and groups and cite a specific issue or policy to explain it. Their responses are thus rooted in their own view of how American politics works. Their view of groups and parties is nonetheless narrow, based on some particular issue and lacking any overarching political or ideological anchor.

\section{Example:}

"I support Obamacare because it really helps a lot of low-income new immigrants. You know there are so many new immigrants who face a lot of financial hardship. I remembered when I first moved to the United States, my whole family hadn't had insurance for almost 10 years, and every time I got sick, I was so afraid to see doctors. But I can only say that I was so lucky. We don't know when we would get ill, the insurance can give us a basic safety net. Therefore, even though I am not very happy with the Democrat on many issues, such as affirmative action, in general they are still better than the Republican Party for minorities."

\section{Level 4: Politicized Identity}

Respondents perceive their ethnic identity as closely intertwined with a political party or ideology. Individuals at this level of Party Conceptualization may also believe that there exists a power struggle between different groups in America and that one of the parties takes their group's side in the struggle. Given such views, a respondent's ethnic identity may largely dictate their partisanship. They may also consider one of the parties as an agent for overall economic and political betterment of America.

\section{Example:}

"I didn't like Hilary Clinton at all. I still voted for the Democratic Party, because in the two-party system I didn't have other options. But I know I will always vote for Democrats. I believe that even if it was not Donald Trump, there will be another Republican candidate who just loves to play the race card. Deep in their heart, they just don't like minorities. Today they picked blacks, tomorrow they will pick Latinos, then they will pick Asians, or Muslims. Because that's what many conservative and ignorant Republicans like to hear." 


\section{The MIMIC Model}

MIMIC models exhibit a combination of econometric-based and psychometric-based approaches (Joreskog \& Goldberger, 1975). The latent variable $y^{*}$ is linearly determined by a set of exogenous variables. $x_{1}, \cdots, x_{k}$ :

$$
y^{*}=a_{1} x_{1}+\cdots+a_{k} x_{k}+\epsilon
$$

The latent variable determines linearly a set of endogenous indicators $y_{1}, \cdots, y_{m}$ :

$$
\begin{gathered}
y_{1}=\beta_{1} y^{*}+u_{1}, \\
\vdots \\
y_{m}=\beta_{m} y^{*}+u_{m},
\end{gathered}
$$

Where the disturbances are all mutually independent with unknown variances, $\epsilon \sim N\left(0, \sigma^{2}\right)$.

\section{Robust Check}

\section{Standardized Residual Matrices}

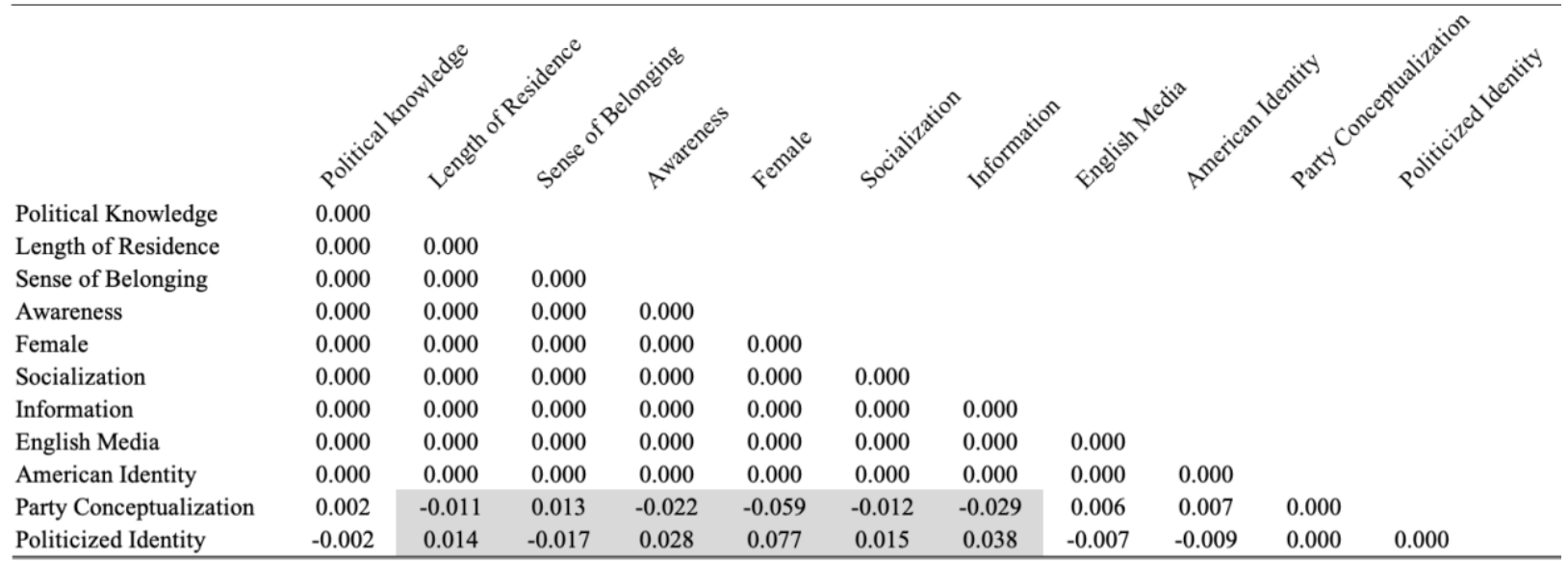

Table A3: Standardized residual matrix (see Figure 3) 


\begin{tabular}{lllllllll}
\hline & \multicolumn{8}{c}{ Standardized Residual Matrix } \\
& P. Interest & P. Know. & Belonging & Awareness & Eng Med & Am ID & P. Conc & P. Identity \\
Political Interest & 0.000 & & & & & & & \\
Political Knowledge & 0.024 & 0.000 & & & & & & \\
Belonging & -0.076 & 0.035 & 0.000 & & & & & \\
Awareness & 0.107 & -0.019 & 0.037 & 0.000 & & & & \\
English Media & -0.033 & 0.017 & 0.033 & -0.158 & 0.000 & & & \\
American Identity & -0.055 & -0.012 & 0.000 & 0.042 & 0.062 & 0.000 & & \\
Party Conceptualization & -0.080 & 0.003 & -0.003 & 0.013 & -0.019 & 0.002 & 0.000 & \\
Politicized Identity & -0.068 & 0.009 & -0.028 & 0.076 & -0.030 & 0.000 & 0.000 & 0.000 \\
\hline
\end{tabular}

Table A4: Standard residual matrix (See Figure 4)

The standardized residual matrix in Table A.3 shows the differences between a model-implied covariance structure to a sample covariance structure. Table A.4 shows that most residuals are close to zero, meaning that the sample covariance structure is well reproduced according to the model. However, the covariance residual between awareness and political interest, and awareness with English media consumption tend to be greater than .1. This means that these pairs of variables are not correlated very well.

\section{Robust Check for Goodness-of-Fit Indices in SEM Model}

The model was estimated by the methods of maximum likelihood (ML) and reweighted least squares (RLS). It is evident that the model fits the data quite reasonably well. The $\chi^{2}$ goodnessof-fit test based on ML method is 21.01 based on 17 degrees of freedom, together they yielded a $\mathrm{p}$-value $=.14$. The $\chi^{2}$ goodness-of-fit test based on RLS is 20.06, and p-value is .17. This means that the model-implied covariance structure is satisfactorily reproduced by the sample covariance structure. Thus, the model cannot be rejected, since it is extremely consistent with the data. Other goodness-of-fit indexes lend us stronger confidence. NFI is .951, CFI is .99, and RMSEA is .033.

The generalizability of findings can be examined from model specifications and model fit. The number of quality indicators of some factors may be inadequate to permit easy detection of misspecifications related to those factors, and hence the measurement status of indicators is critical to draw reasonable conclusions about a model. The basic model specification is such that we have selected only part of the data to be analyzed. The matrix to be analyzed will differ from the input matrix if we hold some measured variables fixed for identification purposes, or free some variables, resulting in adding and dropping parameters. Therefore, it is valuable to check different model specifications to be sure that the rearrangement is accomplished correctly. If these variant models are equivalent, they should produce identical model fit indices. 


\begin{tabular}{lllllllllll}
\hline & & \multicolumn{1}{l}{ Goodness-of-Fit Tests for Variants of SEM Models } & \\
Variance & Variable & Covariance & $d f$ & $\chi_{M L}^{2}$ & $P$-value $(\mathrm{ML})$ & $\chi_{R L S}^{2}$ & $P$-value $(\mathrm{RLS})$ & NFI & CFI & RMSEA \\
F1, F2=* & Party Conceptualization=1 & F1, F2=* & 15 & 21.006 & 0.137 & 20.063 & 0.170 & 0.951 & 0.985 & 0.043 \\
F1, F2=* & Politicized Identity=1 & F1, F2=* & 15 & 21.006 & 0.137 & 20.062 & 0.170 & 0.951 & 0.985 & 0.043 \\
F1, F2=1 & Politized Identity=1 & F1, F2=1 & 16 & 21.006 & 0.178 & 20.061 & 0.217 & 0.951 & 0.988 & 0.038 \\
F1, F2=1 & Party Conceptualization=1 & F1, F2=1 & 16 & 21.006 & 0.178 & 20.061 & 0.217 & 0.951 & 0.988 & 0.038 \\
F1, F2=* & Politicized Identity=1 & F1, F2=1 & 16 & 21.006 & 0.178 & 20.061 & 0.217 & 0.951 & 0.988 & 0.038 \\
F1, F2=* & Party Conceptualization=1 & F1, F2=1 & 16 & 21.006 & 0.178 & 20.061 & 0.217 & 0.951 & 0.988 & 0.038 \\
F1, F2=1 & Politicized Identity=1 & F1, F2=* & 17 & 21.006 & 0.226 & 20.061 & 0.271 & 0.951 & 0.990 & 0.033 \\
F1, F2=1 & Party Conceptualization=1 & F1, F2=* & 17 & 21.006 & 0.226 & 20.061 & 0.271 & 0.951 & 0.990 & 0.033 \\
\hline
\end{tabular}

Note: ${ }^{*}=$ free to be estimated; $1=$ fixed

Table A3: Goodness-of-fit tests for variants of SEM models

To evaluate this proposition, different modifications were analyzed. As Table A3 shows, variance, variable and covariance of interest can be free to be estimated as indicated by “*”, or held fixed at the value of 1.0. As we can see, the program produced optimal estimates for the remaining free parameters under different model specifications: the chi-square statistic remains stable across all models. The p-values derived from RLS tend to be slightly larger than those derived from ML, and all of the p-values clearly > .05. In addition, NFI, CFI and RMSEA remain highly equivalent across all models, and collectively they show a reasonably good fit. 